\title{
How Constitutional Concerns Framed the US Contribution to the International Human Rights Regime From Its Inception,
}

\author{
1947-53
}

Hanne Hagtvedt Vik**

The United States has been reluctant to agree to binding international human rights instruments ever since the very first meeting of the United Nations Commission on Human Rights in 1947. This article explores structural causes for that reluctance. Internal government papers show that US government officers worried that a human rights treaty might expand federal jurisdiction at the expense of the jurisdiction of the USA's constituent states and could provide an opening for judicial activism by the courts. These concerns made domestic political sensitivities more acute and raised principled questions about the desirability of pushing domestic reforms through international lawmaking. US representatives made repeated efforts to ensure that an international bill of rights was drafted as an aspirational declaration rather than a legally binding treaty. They also proposed clauses designed to delay or limit the domestic effects of any agreement, while reassuring the US Senate that domestic power balances would not be disturbed. Constitutional concerns thus framed the USA's contribution to the creation of an international human rights system from the very beginning.

The United States and Somalia are the only United Nations member-states that have not ratified the Convention on the Rights of the Child (1989). In the case of the USA, this nonratification appears incomprehensible at first glance: It is a wealthy country with a longstanding domestic bill-of-rights tradition, yet it has not become party to the world's most ratified human rights treaty. Since February 1995 it has been a signatory to the treaty, but as

\footnotetext{
** Dr. Hanne Hagtvedt Vik, Post Doctoral Fellow at the Forum for Contemporary History, University of Oslo, Oslo; and International Security Program Research Fellow at the Belfer Center for Science and International Affairs, Harvard Kennedy School, Cambridge, MA (2011-2012).

E-mail: h.h.vik@iakh.uio.no.

I am grateful to commentators and panellists at the 2008 Annual Convention of the International Studies Association and to the 2011 meeting of the Oslo Contemporary International History Network, where earlier versions of this article were presented. I would also like to thank Kjersti Brathagen, Sally Cummins, Sönke Kunkel, Paul Gordon Lauren, Helge Pharo, Katarina Rietzler and Jay Winter for helpful suggestions during the research for and writing of this article. A special note of gratitude is extended to the two anonymous reviewers for the International History Review.
} 
of 2011 and despite expressions of support by Barack Obama’s administration - the treaty has not been transmitted to the Senate for its advice and consent. This example forms part of a clear pattern: The United States either does not ratify human rights treaties or does so many years, or even decades, after a treaty has been adopted by the United Nations or elsewhere. When it does ratify, the United States attaches reservations, understandings and declarations to its ratification. ${ }^{1}$

The USA's practice of non-ratification or only conditional ratification has a history that stretches back to the very first days of the international human rights system. ${ }^{2}$ This article revisits the country's preparations for the sessions of the UN Commission on Human Rights (UNCHR), beginning in January 1947 and ending with US Secretary of State John Foster Dulles' 1953 announcement of a no-treaty policy in the human rights field. ${ }^{3}$ Existing accounts have documented a deeply rooted skepticism in the USA towards any proposals that appeared to intrude upon the principle of national sovereignty. The new concept of human rights was perceived among many as particularly intrusive. As pointed out by several historians, racism was at the heart of the problem as the many discrepancies between the UN commitment to human rights and existing domestic laws and practices made the USA vulnerable for criticism by foreign governments. This was especially challenging as domestic advocacy groups quickly turned to the UN to contest Jim Crow laws and demand effective federal intervention to stop lynching. ${ }^{4}$ Furthermore, as Carol Anderson has pointed out, neither Harry S. Truman nor Dwight D. Eisenhower, the two presidential incumbents in the period, were personally committed to creating a strong system for international human rights protection. In general terms, both felt a need to placate racist and isolationist sentiments at home in order to secure support for their domestic and international political programs. ${ }^{5}$

This article adds another important element to the discussion - the constitutional dimension. Most accounts of US human rights policy in the period concerned mention the view that it would be unconstitutional for the United States to ratify a human rights treaty. Constitutional arguments are generally regarded as being exaggerated or squarely unfounded, often advanced in order to conceal isolationist and racist impulses. In line with such a view, the USA's reluctance to enter into binding obligations is often interpreted as an expression of 'hypocrisy'. ${ }^{6}$ This article takes a different perspective. It explores how the US government 
grappled with potential challenges arising from the US Constitution, and the international and national contexts in which these discussions took place. As will be shown, government officers quickly agreed that the Constitution did not prohibit or limit the United States' ability to ratify a human rights treaty. Ratification would not threaten the US Bill of Rights. However, it might expand the legal authority of the federal government, and courts might subsequently base their decisions on the treaty itself, without waiting for legislation that would bring domestic laws in line with the treaty. As the drafting of the international bill of rights progressed, it became clear that rights of very different character could be included in the treaty. The end result in the USA, it was assumed, could be a series of changes in domestic laws, some probably unforeseen at the time of ratification, along with changes in balances of power between different levels and branches of government. Whether this was desirable was a matter of diverging opinions. But, it put US negotiators in a very difficult position at the UN. Much has changed since the late 1940s and early 1950s - both within the USA and in the international political landscape. However, although today there may be less reason to expect sweeping changes in US domestic laws or power relations as a consequence of treaty-ratification, the structural mechanisms discussed in this article continue to prevail. ${ }^{7}$

\section{A Legally Binding or Aspirational International Bill of Rights?}

Wartime rhetoric and diplomatic efforts by US representatives had played an important role in placing human rights on the agenda of the international conference that created the United Nations in June 1945. Addressing the conference, US President Harry S. Truman pledged the USA's support for an international bill of rights. This bill, he had declared, would become 'as much a part of international life as our own Bill of Rights is part of our Constitution' ${ }^{8}$ This was no small promise. When the UNCHR began its operations, however, the United States soon experienced problems in terms of providing global leadership in the human rights field. One of the main problems was related to the legal form of the future international bill of rights.

Compared to the other governments represented at the UNCHR, the United States went to great length to arrive at a coordinated government policy. The interdepartmental 
Subcommittee on Human Rights and Status of Women (S/HRW; hereafter 'the interdepartmental committee') was established in September 1946 to prepare US human rights policy. Chaired by the Department of State, the committee consisted of representatives from the departments of the Interior, Justice and Labor, along with the Federal Security Agency, some being represented by more than one person. ${ }^{9}$ By October 1947, thirteen months after it had started working, it had held about fifty meetings and produced more than 150 documents. ${ }^{10}$ The Interdepartmental Committee on Social Policy (ISP) regularly reviewed the interdepartmental committee's conclusions, but top officials generally appear to have been little involved in the day-to-day discussions on human rights. They were, of course, involved when instructions and policy papers needed to be approved (or rejected). President Truman's personal engagement in UN human rights issues was limited, but Eleanor Roosevelt who represented the USA at the UNCHR until early 1953, and also served as its chairman for many years, kept in regular contact with him. Their contact strengthened the prestige of the field within the administration, probably contributing to upholding a highprofile US participation in the UNCHR long after the domestic debate had turned negative.

The interdepartmental committee addressed a wide range of problems - some of a political nature, others of a diplomatic, philosophical or legal nature. Difficulties involved in navigating, understanding and agreeing on the complex issues arising from the international bill of rights resulted in repeated and sometimes confused and prolonged discussions. Reviewing the many implications of the question of legal form was a most demanding challenge. In the mid-1940s, the question of promulgation, or legal form, was an abstract issue for most of the proponents of the international bill of rights both within the United States and internationally. This is not surprising. Human rights was but one of many fields that were the focus of international lawmaking after the Second World War. International law would undergo a dramatic development in scope and detail, but at the time major issues relating to international lawmaking were still unsettled, including issues such as the status of reservations to international treaties. ${ }^{11}$ Furthermore, agreeing simultaneously on which rights to include and the legal form of the international bill of rights created very complex discussions. This complexity had previously led both the Department of State and the American Law Institute's 'Model International Bill of Rights Project' to bypass the issue of 
legal form in relation to an international bill of rights in their studies on the post-Second World War international order. ${ }^{12}$

The United Nations, however, could not bypass the issue. The question of legal form was on the table as early January 1947 when the UNCHR met for its first session as a permanent commission. UN human rights director John P. Humphrey, a Canadian with a background as a professor of law at McGill University, had prepared a draft outline of the international bill of rights. Drawing inspiration from existing drafts and rights' clauses of national constitutions, Humphrey included a wide range of rights, including freedom of speech, rule-of-law principles, and rights to work, education, housing and social security. ${ }^{13}$ Humphrey advised the UNCHR that the proposed international bill of rights could be adopted either as a multilateral treaty to be ratified by states, as an amendment to the UN Charter, or as a resolution of the UN General Assembly. Humphrey preferred the first option. The UNCHR commissioners took very different positions on the legal form of the international bill of rights. Some favored drafting it as an aspirational document, others as a legally binding treaty. The UNCHR failed to quickly settle the issue. Instead, it worked on three documents simultaneously: one was a declaration of human rights; another was a binding treaty, called a 'covenant'; the third was a document on measures of implementation. In late 1947, the UNCHR decided that the three documents would together constitute the international bill of rights. ${ }^{14}$ The parallel drafting in this early period affected the positions UNCHR commissioners took on important questions, including the scope of rights to be included in the future international bill of rights. This was particularly true in relation to the United States.

The interdepartmental committee's initial position was to draft an aspirational declaration covering a wide-raging body of rights, followed by one or more conventions, possibly dealing in a 'piecemeal' fashion with the rights outlined in the initial declaration. ${ }^{15}$ Accordingly, the United States suggested to the UN that a human rights declaration should include rights that were already familiar from the US Constitution's Bill of Rights - the rights to freedom of speech, information, religion and property, as well as procedural rights, the right to citizenship and the right of citizens to participate in their government. Moves towards greater emphasis on government responsibility for individual welfare were well underway 
within the United States as a result of the political responses to the Great Depression and the Second World War itself. ${ }^{16}$ The US proposals reflected this ongoing expansion of the concept of rights through their suggested inclusion of social rights, such as the right to employment and social security, along with the 'right to enjoy minimum standards of economic, social and cultural well-being'. ${ }^{17}$

Among the proposals presented to the UNCHR, however, were the kernels for both a declaration and a covenant. Like Humphrey, the United Kingdom favored adopting the international bill of rights as a legally binding treaty. A very important difference, however, was that the UK proposal was more limited in scope, containing only civil and political rights. ${ }^{18}$ Before the 1947 summer session, it had become clear to the Department of State that 'a strong movement' had developed within the UNCHR 'for the immediate undertaking of a Convention'. Out of a desire to avoid the embarrassment of finding itself belonging to a minority, the United States decided to go along with the proposals for a convention, in addition to the proposed declaration. ${ }^{19}$

Why did the USA hesitate to support the drafting of a human rights covenant? Discussions in the interdepartmental committee had highlighted several arguments against the treaty approach. First, drafting a legally binding treaty was seen as being more complicated, as it would require 'much time' and could only result in a treaty with a 'very brief list' of rights. ${ }^{20}$ The treaty approach to the international bill of rights also raised the question of whether the US Constitution limited the power of the government to make treaties in a way that applied to this specific case. The question of constitutional limitations on the treatymaking power was well known to many of the government lawyers involved. But, as with almost any group of lawyers, their interpretations of the relevant legal principles varied, which initially caused some problems. Two problems were discussed at some length.

The first of these was whether human rights were a subject 'of international concern'. In an obiter dictum - that is, a non-binding observation - the US Supreme Court had earlier held that, in addition to the requirement that it not violate any specific prohibitions set out in the Constitution, exercise of the power to make treaties was permitted only in relation to questions of international concern. ${ }^{21}$ In the committee, Marjorie Whiteman, who represented the Department of State Office of the Legal Adviser, argued that the question of whether 
human rights were a subject 'of international concern' had to be answered from the standpoint of the United States. The fact that human rights had been included in another treaty, the UN Charter, did not in itself make such rights an appropriate subject for a treaty to be entered into by the United States. ${ }^{22}$ In her view, the question had to be assessed 'in the light of the substantive articles to be included in the Convention'. ${ }^{23}$ Accordingly, a final decision on whether the federal government could ratify such a treaty would have to wait until the actual text of the treaty had been finalized. For Herzel Plaine of the Department of Justice and the majority of the interdepartmental committee's members, the litmus test was whether the subject matter of the treaty was 'appropriate' for incorporation in an international agreement, which was a much more generic judgment. ${ }^{24}$ The committee decided to work under the presumption that the issue of human rights was a question 'of international concern'.

The second problem was whether there existed a body of 'state rights' that made ratification of the treaty unconstitutional. This problem was considerably more difficult than the first. Many of the rights that were discussed for the international bill of rights concerned policy areas that were within the jurisdiction of each of the USA's forty-eight constituent states. The states' rights problem was related to the doctrine of 'dual federalism' and what legal scholar Edwin Corvin had described as the 'once strongly held theory that the "reserved powers" of the States, or an inner core thereof, stand on a level with the constitutional powers of the National Government'. ${ }^{25}$ The Supreme Court, however, had already rejected the claim that the Tenth Amendment limited the treaty-making power of the federal government on numerous occasions. ${ }^{26}$ In the light of this, it is somewhat surprising that the minutes of the interdepartmental committee reveal uncertainty as to whether there existed a body of states' rights that could make ratification of a human rights treaty unconstitutional. Marjorie Whiteman, however, argued forcefully against such a view. According to her, there could be no doubt that as long as the treaty in question dealt with a subject of an international character and did not run counter to an express prohibition in the Constitution, the United States could ratify it. ${ }^{27}$ This was probably not equally clear to all of the other members of the committee, however, as the minutes still referred to 'some doubt' expressed over areas where the 'State alone has legislative power to afford protection'. ${ }^{28}$ 
In early October 1947, the interdepartmental committee concluded that the federal government possessed the constitutional jurisdiction necessary to ratify a human rights treaty. ${ }^{29}$ And, although some highly critical lawyers representing the American Bar Association later claimed it would be 'unconstitutional' to ratify a human rights treaty, most legal scholars seemed to agree with the conclusion that the federal government could lawfully become party to a human rights treaty. Whether it was desirable was a very different question, and one that the committee had barely begun investigating at this point. Here they faced a more complex set of challenges of both a legal and political nature.

Once ratified, a treaty becomes the 'supreme law of the land' according to the second paragraph of Article VI of the Constitution, which reads:

This Constitution and the laws of the United States which shall be made in pursuance thereof; and all treaties made, or which shall be made, under the authority of the United States, shall be the supreme law of the land; and the judges in every State shall be bound thereby, anything in the Constitution or laws of any State to the contrary notwithstanding.

This supremacy rule had two important effects. First, according to longstanding precedent, including the decision in the landmark case of Missouri v. Holland in 1920, a treaty could provide the federal government with the necessary constitutional jurisdiction to legislate within policy areas previously reserved for the states. Hence, as Whiteman reminded the committee, a treaty could enlarge the powers of the federal government vis-à-vis the states. ${ }^{30}$ Secondly, once ratified, courts could on many occasions apply the provisions of a treaty in their judgments, without waiting for national legislation to guide their interpretation of it. In essence, this meant that a treaty embodied the potential of shifting domestic power balances: ratification might enhance federal jurisdiction over subject issues previously reserved for the constituent states, and enhance the power of the courts at the expense of legislators. As we shall see, some saw in this the potential for positive changes within the United States. Others saw problems of various kinds - from negative effects upon the USA's international prestige to undesirable political outcomes within the United States itself.

Entering into these more detailed discussions, members of the interdepartmental committee seemed unprepared, even surprised, over the possible effect of a future human 
rights covenant upon domestic laws and practices. Accordingly, when participating in drafting the covenant, the main question for the US government became whether the existing balance of power between the federal level of government and the constituent states, and between the legislative and judiciary powers, could and should be retained. The 'could question' was a legal one, while the 'should question' was one of constitutional policy. The political interests of the involved agencies and the personal convictions of government officers and external advisers weighed in heavily on the latter question. In the evolving discussions, however, the 'could' and 'should' questions were all mixed up. This was true for discussions both within and outside the government.

\section{Proponents and Adversaries of Expansion of Federal Jurisdiction}

By the late fall of 1947, the interdepartmental committee members were working from the presumption that depending on which rights were eventually included in the treaty, ratification would to a varying degree involve an expansion of federal jurisdiction at the expense of the states. The committee identified two possible strategies that might help circumvent the problem of state and federal jurisdictions. The first was to pay close attention to the proposed rights in order to minimize inconsistency between the future human rights covenant and existing federal and state laws and practices. The committee therefore considered in details the relevant domestic laws and practices for every proposed right. The other strategy the committee came up with was to include a federal-state clause in the covenant. ${ }^{31}$ This was seen as a realistic option given the existence of a similar provision in the 1946 Charter of the International Labour Organization (ILO). The ILO provision made clear that a convention 'which the federal government regards as appropriate under its constitutional system, in whole or in part, for action by the constituent states' was to be referred to the states for enactment of legislation or other action. The federal government would only be obliged to carry out periodic consultations with local authorities and report to the UN secretary-general on the status of treaty implementation. ${ }^{32}$

The interdepartmental committee anticipated that the inclusion of a federal-state article would shield the United States from international criticism in relation to legislation 
and practices at the sub-federal level that were inconsistent with the terms of an international agreement. Such a clause would also be helpful in convincing the Senate to support ratification of the covenant. Department of State officers argued that a federal-state clause would help avoid 'a tremendous political struggle'. ${ }^{33}$ However, the committee discussions also brought to the surface various arguments against such a clause. One was that few countries shared the concerns of the United States in relation to this issue. Committee members therefore expected that inclusion of a federal-state clause would make it more difficult to secure international acceptance for the bill of rights. ${ }^{34}$ Another argument related to US pressure groups. The representative from the Department of Labor warned the committee that if the decision was made to push for a federal-state clause in the human rights covenant, this could be expected to disappoint US NGOs. ${ }^{35}$ Such a development was seen as undesirable in view of the need to retain domestic support for an active US role in the new world organization.

Department of State representatives turned out to be the most active proponents for a federal-state clause, whereas representatives from the departments of Labor and Justice advocated taking on the domestic political fight to achieve ratification of a treaty without the federal-state clause. ${ }^{36}$ These divergences in opinion should be interpreted with some caution. It is not necessarily the case that the disagreements marked clear differences of opinion between the various departments. The relevant discussions took place within the context of an interdepartmental committee, in a process aimed at sorting out the issues involved and during early strategic discussions. The sources utilized do not reveal the extent to which the views expressed were cleared with top officials. ${ }^{37}$ Nevertheless, there is some basis for speculation as to the reasons for the diverging views.

The Department of Labor's position might be understood in the light of its ambitions in national and international social policy. In 1946, a division for international affairs led by David A. Morse had been established within the department. Accordingly, as assistant secretary for international affairs, Morse was most likely the responsible top official for the Department of Labor's involvement in the interdepartmental committee. Morse was committed to Roosevelt's New Deal policies and had ambitions to extend such visions into the international field. ${ }^{38}$ The ILO, as we have seen, had a federal-state clause in its 
constitution, due to US insistence. It may be that the possible human rights covenant offered an opportunity to circumvent this problem by providing an alternative platform for pursuing domestic reforms with the help of international legislation. However, I have seen no direct or even persuasive circumstantial evidence for such a hypothesis. And, the fact that the draft covenant did not yet include social rights speaks against such a speculation.

The circumstantial evidence is stronger regarding the reason behind the diverging views expressed by the representatives of the departments of State and Justice. The Department of Justice was responsible for enforcing national civil rights legislation, and this may explain why it was more concerned with the possible help it could get from a human rights covenant. The Jim Crow laws in the southern states mandated segregation of public spaces as well as in education, employment, and housing, prohibited interracial marriages and limited voting rights. Across the United States, racial segregation and discriminatory practices permeated all levels of society; formal discrimination was matched with informal mechanisms, resulting in varying degrees of race-based political, social and economic deprivation. Afraid of eroding support for his New Deal legislation, President Roosevelt had been hesitant to support civil rights legislation, including an anti-lynching bill. Some steps had nevertheless been taken to engage with the issue of racial discrimination. In 1939, a Civil Rights Section had been established within the Department of Justice, and members of this section were responsible for early attempts to expand federal jurisdiction in the field of civil rights through federal intervention in court cases. In June 1941, Roosevelt issued an executive order creating the Fair Employment Practices Commission. ${ }^{39}$ President Truman continued this careful line, and his 1946 Executive Order 9981 that officially ended racial segregation in the US Armed Forces was a major political accomplishment. However, though significant politically, such initiatives yielded only very modest results in terms of reducing or ending racial discrimination within the United States. ${ }^{40}$

The interdepartmental committee pointed out in the summer of 1947 that ratification of a human rights treaty might 'help overcome any constitutional problems that might stand in the way of improving our national legislation on civil liberties'. ${ }^{41}$ The Department of Justice therefore may have seen the covenant as providing a favorable platform for domestic reforms. Another possible explanation for the diverging opinions on the federal state clause 
relates to the scope of expected changes in domestic laws and practices. In the committee, a Department of Justice representative offered the opinion that the rights proposed by the United Kingdom were already protected by the federal constitution. The only exception was the proposed discrimination clause, which he believed went considerably further than the guarantees contained in the US Constitution. ${ }^{42}$ Department of State representatives, however, doubted this and believed there were greater discrepancies. The department's Bureau of International Organization Affairs therefore proposed to ask the Attorney General for a formal opinion on constitutional and legal questions arising from the draft human rights covenant. Following the recommendation of legal adviser Charles Fahy that such a procedure be postponed until the terms of the convention had been 'worked out and politically decided upon fairly firmly', the interdepartmental committee chose not to involve the Attorney General at this point. Instead, it continued to study the implications of the specific proposals of the draft convention. ${ }^{43}$ The committee thereby chose to abstain from an authoritative legal opinion on the complex issues they were struggling with.

The departments' diverging instincts on the covenant were illustrated six months later in President Truman's 2 February 1948 speech to Congress, which was prepared by the Department of Justice. This speech introduced a civil rights package that included measures against lynching, the levying of a poll tax and segregation on public transportation, as well as the establishment of a permanent Fair Employment Practices Commission. ${ }^{44}$ Contextualizing the civil rights proposals, the Department of Justice had Truman state that the United States was playing a leading role in developing the international human rights covenant. ${ }^{45}$ The Department of State, however, disagreed and protested to the Department of Justice, pointing out that the United States was a driving force behind the declaration, but not the covenant. ${ }^{46}$

It is therefore reasonable to expect that the disagreements between the departments of State and Justice mirrored the fact that top officials, or at least the responsible bureaus of these departments, actually viewed the two documents under drafting in the United Nations differently. The picture that emerges is thus one in which the Department of Justice representatives saw the future human rights covenant as desirable for securing progress in domestic racial policies, whereas the Department of State representatives feared a covenant would have much larger, and unpredictable, effects upon domestic laws and practices. The 
Department of State saw this as undesirable for reasons of principle, in that it would transfer substantial areas of domestic lawmaking to the domain of international negotiations - race relations being the most immediate concern, especially for top officials. But, it was also undesirable for strategic reasons, given that a Senate refusal to agree to ratification would cause considerable international embarrassment for the United States.

At the December 1947 session of the UNCHR, the United States gained acceptance for the inclusion of a federal-state clause in the draft covenant. If accepted, the clause would be Article 24 of the Draft International Covenant on Human Rights, which read:

In the case of a Federal State, the following provisions shall apply: (a) With respect to any Articles of this Covenant which the federal government regards as wholly or in part appropriate for federal action, the obligations of the federal government shall, to this extent, be the same as those of parties which are not federal states; (b) In respect of Articles which the federal government regards as appropriate under its constitutional system, in whole or in part, for action by the constituent State, Provinces or Cantons, the federal government shall bring such provisions, with a favourable recommendation, to the notice of the appropriate authorities of the States, Provinces and Cantons. ${ }^{47}$

This was only a temporary victory. The federal-state clause would continue to cause serious disagreement within the UNCHR - so much so that in 1950 the Lebanese commissioner and UNCHR rapporteur Charles Malik identified the federal-state clause as 'one of the major hurdles which might mean the making or the breaking of the Covenant' ${ }^{48}$ It was but one hurdle. Internationally, the rising Cold War tensions made it almost inconceivable that states in the foreseeable future would be able to agree to a legally binding statement of fundamental rights. For the United States, the main problem was a difficult domestic political situation, further complicated by the supremacy clause of the Constitution. As we shall see, a similar situation developed in the UNCHR on the implementation article: the USA asked for formulations that might help circumvent a particular problem, and were met by lack of understanding and arguments that such formulations would unnecessarily reduce the strength of the future treaty. 


\section{Might a human rights treaty lead to a rapidly evolving case law?}

In line with the discussions over a declaration or a covenant, some UNCHR commissioners pursued the strongest possible wording on national implementation. For example, at the December 1947 UNCHR session, the Working Group on the Question of Measures of Implementation recommended that for states that had a constitutional system that permitted the 'immediate application' of treaties, this solution for implementation 'should certainly be adopted'. ${ }^{49}$ The United States, on the other hand, promoted with increasing vigor a special provision that would strengthen legislative control over federal and state courts' application of the covenant, the so-called non-self-executing provision. The supremacy clause of the US Constitution made many treaties self-executing, which meant that courts in principle were obliged to consider treaties when deciding a specific case. What might transpire was a case law that developed faster than would have been the case without the treaty, a development sometimes called 'judicial activism' to signal the centrality of the political views of some judges upon their decisions. The main challenge with the human rights covenant in this respect was its very general wording: how could one possibly predict how judges would interpret its provisions, both immediately after its ratification and also in the longer term?

Initially, this caused little concern among the members of the interdepartmental committee. Article 2 of the draft covenant made clear that each ratifying state was obliged to ensure that its 'laws secure to all persons under its jurisdiction ... the enjoyment of these human rights and fundamental freedoms’ ${ }^{50}$ Reporting home in May 1948, the US delegation pointed out that a major accomplishment was the covenant-drafting committee's acceptance of the US proposal for Article 2. This article's first part now read:

Every state party hereto undertakes to ensure: (a) Through adequate laws and procedures to all individuals within its jurisdiction, whether citizens, nationals, persons of foreign nationality or stateless persons, the rights and freedoms set forth in part II of this Covenant, and further undertakes that such rights and freedoms where not now provided under existing laws and procedures be given effect in its domestic law through the adoption of appropriate laws and procedures. ${ }^{51}$ 
In the eyes of the US delegation, the reference to the need for national legislation to implement the covenant made the whole covenant non-self-executing. ${ }^{52}$ Further strengthening this impression, the UNCHR Drafting Committee agreed to insert a footnote to its report, making clear that the 'Covenant is not self-operative'. ${ }^{53}$ The UNCHR, concentrating on finishing the draft declaration, forwarded the draft covenant to the UN Economic and Social Council (ECOSOC) without changes. ${ }^{54}$

US government officers grew increasingly worried over domestic implementation issues. In the late fall of 1948, the interdepartmental committee decided that explicit reference should be made in the covenant itself to the fact that it was not intended to be a self-executing treaty. The increasing uneasiness was due to both internal discussions and external pressure. Internal government discussions had revealed uncertainty over how domestic courts would interpret the covenant if it were ratified by the United States. The interdepartmental committee now held that it was extremely difficult to foresee 'the effect of the present Covenant on existing law in all circumstances'. ${ }^{55}$ According to the minutes of its meetings, the new Article 2 should read: 'Every State party hereto, recognizing that this covenant is not intended to be self-executing, undertakes to ensure, through the adoption of adequate laws and procedures, the rights and freedoms set forth in this covenant' ${ }^{56}$ This was in line with advice given by external advisers. Earlier that year, Harvard professors Manley O. Hudson and Zechariah Chafee, Jr., had advised the Department of State that insufficient attention was being paid to the US constitutional system. ${ }^{57}$ Hudson found the existing formulation in Article 2 to be 'highly unsatisfactory'. The draft covenant declared a series of rights in absolute form. In his opinion, by depending on a single statement to reduce the obligations imposed by the treaty to an obligation to legislate, the draft opened for a development whereby the Supreme Court over time would overlook this article and apply the other provisions regardless. ${ }^{58}$

The uneasiness of the interdepartmental committee was also caused by the legal community's growing interest in the UN's human rights efforts. Opinions were increasing in volume and intensity, and a number of critical articles and editorials had been published in the American Bar Association Journal. ${ }^{59}$ Furthermore, taking an opposite position, some lawyers and pressure groups were invoking the human rights provisions of the UN Charter in 
domestic court litigation. Thus, the dynamic potential of international human rights instruments was already being tested in US courtrooms. The background for this was that the establishment of the United Nations had created new opportunities for African-American organizations to pressure the US federal government to act on the economic and social problems of the USA's black population and challenge state tolerance of the practice of lynching, segregationist policies and other discriminatory practices. Both the nondiscrimination principle and the social-justice formulations of the UN Charter stood in stark contrast to the everyday experiences of the non-white population of the United States. With the Charter in hand, pressure groups did not want to wait for the promised international bill of rights.

African-American pressure groups had participated in lobbying efforts directed at the Department of State during the late war years, including during the establishment of the United Nations. Now they petitioned the United Nations, claiming that the human rights formulations of the UN Charter provided the UNCHR with the power to review these ${ }^{60}$ In the spring of 1947, the Commission responded to these and many other petitions by declaring that it did not have the competence to engage in individual cases, a decision that was highly criticized both in contemporary and in more recent scholarship. ${ }^{61}$ None of the petitions were put on the General Assembly agenda. They did, however, receive wide publicity within and outside the United States.

Parallel to petitioning the UN, the National Association for the Advancement of Colored People (NAACP) tried to use the Charter formulations in court cases. In October 1947, the NAACP approached the American Association for the United Nations (AAUN) to request that the Association file a brief as amicus curiae in two cases of discrimination that were then before the US Supreme Court. In both cases, African-Americans had been evicted from their homes because the previous owners of those homes had signed written agreements designed to keep non-whites from the use of property in certain residential areas, so-called restrictive covenants. The NAACP sought a brief that would reinforce arguments used in lower courts that the Fourteenth Amendment prohibited courts from lending aid to the enforcement of contracts based on religious or racial discrimination, and that the eviction of 'negroes' was also a violation of the UN Charter, which now had become the supreme law of 
the land. ${ }^{62}$ Several organizations intervened in this case, including the AAUN which filed a brief on 8 December 1947, with the signatures of Alger Hiss, Asher Bob Lans, Philip C. Jessup, Joseph M. Proscauer, and Myres S. McDougal. The brief followed the argument suggested by the NAACP that enforcement of restrictive covenants represented a violation not only of the US Constitution but also of the UN Charter, which had to be regarded as the law of the land in relation to the specific cases at hand. ${ }^{63}$

The President's Committee on Civil Rights made a similar argument in its landmark report To Secure These Rights, issued the same month. 'A strong argument' could be made that the UN Charter empowered Congress to pass legislation 'designed to secure "respect for, and observance of, human rights and fundamental freedoms for all without distinction as to race, sex, language, or religion”'. The Committee also referred to the ongoing work by the UNCHR in drafting an international bill of rights and suggested that 'an even stronger basis for congressional action under the treaty power may be established' if that document was 'accepted by the United States as a member state' ${ }^{64}$ Such formulations, like those of the AAUN brief, left no doubt that the human rights activities of the United Nations would be used to circumvent the powerful forces that currently had the upper hand in the civil rights field.

The attempts to utilize international human rights provisions in domestic courts were controversial. AAUN member Benjamin Cohen, who had been a key actor in the White House's engagement in international human rights as part of wartime diplomacy, refused to sign the amicus brief. He had expressed support for a brief to an AAUN October meeting but could not support the completed brief. Cohen explained that, in his view, the legal argument should not invoke international obligations. He gave two reasons for this. First, he believed the Supreme Court should use the 'due process' and 'equal protection of the law' clauses of the US Constitution's Fifth and Fourteenth Amendments to make clear that US municipal laws prohibited discrimination. Second, by invoking the UN Charter's provisions on human rights, Cohen thought that the Association would 'give currency to arguments that would make it most difficult to get any treaty or declaration of human rights accepted in the Senate without stultifying reservations’ ${ }^{65}$ 
This was also the view taken by the Truman administration. Parallel to the efforts by the NAACP and the AAUN, the Department of Justice filed an amicus brief in the same cases. The department argued that enforcing restrictive covenants was a violation of the Fourteenth Amendment. The Supreme Court agreed with this line of argument and ruled that the restrictive covenants could not be enforced. ${ }^{66}$ Thus, the complaint was decided in favor of those who had been evicted from their properties, but the decision was not based on the human rights provisions of the UN Charter. Attempts to utilize UN human rights efforts in domestic courts were hotly debated within the legal community at the time. ${ }^{67}$ In hindsight, both legal historians and historians of human rights have concluded that international pressure on the United States was a major factor behind the Truman administration's support for several desegregation lawsuits. Some have also argued that the development of international human rights helped convince the US Supreme Court to expand the US Constitution's protection of individual rights. ${ }^{68}$ The Supreme Court itself, however, consistently denied any legal effect of the Charter formulations on human rights and based its decisions - including the landmark ruling in the 1954 case of Brown. v. Board of Education solely on the US Constitution. ${ }^{69}$

\section{The Road to the No-Treaty Policy}

On 10 December 1948, the UN General Assembly adopted the Universal Declaration of Human Rights. The day before, the Assembly had adopted the United Nations Convention on the Prevention and Punishment of the Crime of Genocide. The timing was crucial. The ongoing Arab-Israeli war, the Soviet-Allied struggle over Europe (including the Allied airlift to Berlin in response to the Soviet blockade and the announcement of the Truman doctrine), and the escalating tensions over the Korean peninsula all contributed to the sense that time was working against the UN human rights project - both internationally and within the United States. Meeting again in 1949, the UNCHR continued steadfastly with its efforts to finalize the second part of the international bill of rights - the human rights covenant.

With the Declaration completed, some commissioners sought to include social and economic rights in the legally binding instrument as well. The UNCHR therefore asked the 
UN Secretariat and the governments of UN member-states to prepare and discuss appropriate articles. ${ }^{70}$ For the US government officers, the wider the scope of the draft covenant, the more difficult it became to foresee its possible domestic effects, which made it more important to include formulations that could persuade the Senate that the covenant would not disturb domestic political power balances. Attempts to secure UNCHR support for a federal-state clause and a non-self-executing provision, however, revealed several problems.

First of all, although US representatives regularly argued the opposite both within the UNCHR and domestically, the United States could ratify a treaty without a federal-state clause. Such a clause was expedient politically, however, as the Senate held the upper hand in US treaty-ratification procedures through the Constitution's requirement of a two-thirds majority vote in support of ratification. But could such a clause do what it promised? The many revisions of the federal-state proposals, indicate that government officers searched for a formulation that was not only useful to persuade Senators, but might also have the declared effect of leaving the federal and state jurisdictions unaltered. Among those who apparently believed this could be achieved was John Foster Dulles, a key figure in the foreign policy caucus of the Republican Party and a member of the US delegation to the United Nations. When consulted on the ongoing drafting of the human rights covenant, he proffered the view that 'something like' the federal-state clause was 'desirable' as it would be 'unwise' for the federal government to attempt to acquire 'the right and duty to enforce human rights throughout the United States without regard to states rights', thus indicating his belief that such a formula could be found. ${ }^{71}$ Within the committee, Marjorie Whiteman argued against such a view. The federal-state clause would be useful, as it would enable the State Department 'to tell the Senate that the Covenant does not disturb States' rights'. It would, however, be anachronistic as federal jurisdiction would expand to include all subject areas of the treaty regardless of the federal-state clause. ${ }^{72}$ Professor Quincy Wright shared this view and advised the State Department that only by naming the United States in the convention itself could expansion of federal jurisdiction be hindered. ${ }^{73}$

The non-self executing article raised a similar problem: the many long discussions and various drafts reveal that government officials believed that a human rights covenant might provide an opening for 'judicial activism' by courts regardless of the different 
formulations of Article 2 that were proposed. Thus, when Department of State representatives argued publicly that the two clauses would guarantee that federal-state jurisdictions were left unaltered and would ensure that the covenant did not open a new platform for achieving domestic reforms through courts, they were probably well aware that that they might be skating on very thin ice. ${ }^{74}$

Another problem for the United States was that its concerns met with little interest and understanding in the UNCHR. Although the effect of treaty ratification was well known in the United States, other countries were not equally concerned with the domestic effects of a covenant. The reason was quite simple: Countries had very different constitutional arrangements when it came to the status and effect of international law. First of all, many were unitary and not federal states. Thus, their UN delegates were appointed by government bodies, which at the time of the negotiations had the jurisdiction to legislate within the subject area of the treaty. Furthermore, few were operating within a context whereby the treaty would become immediately applicable once ratified. The United Kingdom, for example, could champion the covenant knowing that, before it could become effective in the UK, Parliament would have to implement the treaty through domestic legislation. The expression 'self-executing', which was so important to the United States, was therefore not well known outside that country.

The 1950 discussion of the Third Committee of the UN General Assembly is illustrative. Here, a majority of the speakers opposed the inclusion of a federal-state clause, which, they argued, would create considerable disparity between the obligations of unitary states and those of federal states. The United States, Australia and Canada argued forcefully in favor of such a clause. The Netherlands, New Zealand, the United Kingdom, Lebanon, France, Norway and Brazil reluctantly supported a federal-state clause, and wanted the covenant to require that federal states report on the progress made by their constituent units. Turkey and Greece advocated other compromise proposals. And, finally, the Byelorussia, Czechoslovakia, Chile, China, Colombia, Cuba, Denmark, Dominican Republic, Egypt, France, India, Iraq, Mexico, Pakistan, Poland, Ukraine, Uruguay, the USSR and Yugoslavia spoke against. ${ }^{75}$ The reasons for opposing the federal-state clause varied. Denmark, for example, was concerned that the 'strong West German Federal state' would make it difficult 
for the 'small state of Denmark' to ensure that the rights of the Danish minority in South Schleswig were protected. ${ }^{76}$ Chile feared that the colonial powers, and particularly France, would take advantage of the clause in their colonial policies. ${ }^{77}$ The USSR and its satellite states were probably exploiting the question to gain goodwill among the other states opposed to the clause, as well as to embarrass the United States. They were probably not intending to ratify the covenant in any case. In the end, the federal-state article failed to garner the necessary support.

Thus, from the late 1940s, the Department of State faced an increasingly difficult balancing act between the UN negotiations and the domestic public debate. Within the Commission, the USA worked for changes in the draft covenant. At home, the background for these changes could not be truthfully explained, as that would have revealed doubts over whether the present formulations were sufficient and thus give ammunition to domestic critics. This was especially crucial in the fall of 1949, when the Genocide Convention was pending in the Senate: the fundamental questions on federal-state relations also applied to this convention, although the subject matter involved was much more limited. By the spring of 1950, it was clear that the UN secretariat and several commissioners favored including social and economic rights as well as a right to individual petition in the human rights covenant. ${ }^{78}$ The General Assembly followed up by requesting that the UNCHR include 'a clear expression of economic, social and cultural rights' in the draft covenant. ${ }^{79}$ Making matters worse, the UNCHR decided to postpone the final vote on the federal-state clause. ${ }^{80}$ Furthermore, the issue of a right to self-determination had become a recurring theme in the different UN bodies. During the same 1950 session, the General Assembly's Third Committee adopted a proposal calling for the Commission on Human Rights to 'study ways and means which would ensure the right of people to self-determination' ${ }^{81}$ In 1951, Eleanor Roosevelt decided to withdraw from her position as chair after experiencing declining political effectiveness due to increasing resistance to US leadership among the Commission's members. $^{82}$

In the volatile domestic political climate of the late 1940s and early 1950s, the UN's human rights efforts were like carrying petrol to the fire. By the early 1950s, the issue of human rights was no longer an asset for those who wanted the United States to play a leading 
role in the new world organization. Human rights had become a serious liability, in particular owing to escalating domestic anti-communist activism. In May 1952, the greatest single point of attack by UN critics was 'the alleged danger that the rights of American citizens and the power of the American government may be curtailed or destroyed by UN treaties'. ${ }^{83}$ The debate over the UN human rights treaties intertwined with a more general debate over the role of the Executive in foreign policy. At the time, the Senate was considering proposals designed to limit the president's treaty-making power, known as the 'Bricker amendment' controversy. Scholars disagree over the importance of the UN human rights project for the introduction of the different proposals and the support of individual Senators. Where some emphasize the controversial issue of future US ratifications of human rights treaties, others see the amendments as primarily stemming from a resurgence of isolationism in the United States. Regarding this debate's impact upon US human rights policy, however, all agree that Dulles' April 1953 announcement of a no-treaty policy in the human rights field was motivated by his desire to defuse the growing support for the Bricker amendment and similar proposals. ${ }^{84}$

As noted earlier, Dulles had expressed support for the Truman administration's efforts in the human rights field. He had even written in a draft speech in 1949 that international law in relation to human rights must 'stand in need of no intermediate legislations'; rather, it must be the 'law of the land', applicable to individuals and enforceable through the normal procedures of courts. ${ }^{85}$ Three years later, Dulles had made a dramatic change of mind. In April 1952, he gave a speech that would become a point of reference in the swelling domestic debate. In this speech, Dulles was discussing the 1951 Japanese Peace Treaty but framed his argument within the larger question of bipartisanship in the conduct of foreign policy. He opened his speech by declaring that treaties were 'an extraordinary power, liable to abuse'. ${ }^{86}$ Dulles' sweeping statements on the effect of treaties on the US political system, coupled with his claims that keeping human rights as a matter of domestic, rather than international, concern was to adhere faithfully to the constitutional intent, were a gift to the adversaries of the UN's human rights efforts.

Why this change of mind? Nobody has studied how Dulles' views on human rights developed from his advocacy for human rights during the 1940s to his 1953 announcement of 
a no-treaty policy. ${ }^{87}$ The sources utilized for the present article do not reveal his motivations in any detailed fashion. There is some basis for speculation, however. First, Cold War tensions probably strengthened his skepticism towards mechanisms that might open for international intervention into issues he believed were essentially domestic affairs. During the 1945 San Francisco conference, he had warned against including in the UN Charter clauses that might open for international intervention in domestic politics. Human rights clauses had since been included in the Italian and satellite-state Peace Treaties, and possible noncompliance by these states were already hotly debated in the UN - a development Dulles was very critical of. For the Japanese Peace Treaty, Soviet Union had proposed similar terms, 'obviously because such a clause would give them the right to intervene in the domestic affairs of Japan', Dulles asserted. To his comfort, however, the human rights clause was only included in the preamble of the treaty, leaving human rights as a domestic concern. ${ }^{88}$ An international human rights covenant, however, would represent a new platform for these sorts of discussions, and the United States would be vulnerable to criticism. Second, Dulles may have come to the conclusion that a human rights treaty might also have significant effects at home. Eisenhower had promised in his presidential campaign to restore the constitutional balance between the president and the US Congress, a balance that he claimed had been changed by Roosevelt and Truman, who in his opinion had sought too much power for the president. ${ }^{89}$ The Executive, according to Dulles, had used treaties to encroach on Congressional power. The ongoing domestic debate over human rights may have alerted him to the possibility that the covenant might open up for bypassing normal political procedures to achieve domestic reforms. Then, finally, in his role as Secretary of State from 1953, his overriding concern was to secure support for the administration's international ambitions. The human rights covenant was no clear-cut winning issue for the USA at the UN, and it provoked very negative reactions at home. In other words: at this point of time, Dulles probably did not find it very difficult to abandon the human rights covenant and other human rights treaties. Thus, though being among the advocates of human rights prior to the San Francisco conference, Dulles in 1953 turned his back on efforts to finalize the international bill of rights. This was the final stop on the road to a no-treaty policy, a policy that since has 
been modified, though its remnants still place the USA in an exceptional position, particularly in comparison to other Western states.

\section{Conclusion}

How, then, might we explain the approach of the United States to the drafting of an international bill of rights? The US preference for a declaration reflected that the issue of human rights was seen primarily as a visionary, aspirational project. Human rights should accommodate popular demands for a people's peace and a moral world order, and thereby stimulate support for a world organization, both in the United States and elsewhere. The human rights project should also position the United States as the leader of the free world and contribute to its efforts to promote peace, democracy and individual freedom. Many government officers - as well as Eleanor Roosevelt herself - therefore sincerely believed that a declaration was a good idea. A covenant, on the other hand, was expected to have a more limited scope and a more technical language. This would limit its usefulness as an aspirational document. The more serious misgivings towards suggestions for a covenant stemmed from domestic political considerations reinforced by the Constitution's supremacy clause.

Fundamentally, US resistance to treaties in the human rights field in the late 1940s and early 1950s was all about politics. The Constitution did not limit the USA's ability to become party to a human rights treaty, as the government officers involved in preparing US human rights policy at the UN realized after some months of doubt. Thus, the structural mechanisms embodied in the US constitution were not the main reason for the country's hesitant human rights policy during the late 1940s and early 1950s. There were many factors - from domestic racial discrimination, to longstanding controversies over governmental responsibility for public welfare, particularly in relation to the federal government, to rising isolationist sentiments and anti-communist activism - that all in different ways contributed to the lack of political will in the United States to support a strong international human rights system. What this article has argued, however, is that the role of treaties in the US constitutional system helps explain why domestic political sensitivities became so acute when 
faced with the prospect of US ratification of a human rights covenant. From the very first draft, the human rights covenant included rights that were relevant to domestic race relations. Then, as the scope widened, the question of the state's responsibility for social welfare weighed in. Many other issues, including educational policy, criminal law and immigration, were also sensitive in domestic politics and were associated with racial prejudice as well as controversy over what was the proper balance of power between the federal government and the constituent states. Furthermore, the USA's legal culture made lawsuits based on a human rights covenant likely, and activist groups were already trying to use the human rights provisions in the UN Charter to achieve changes at home.

Faced with a treaty that could shift domestic balances of power, US government officers diverged over the appropriateness and strategic soundness of pursuing a human rights covenant. Department of Justice officers seemed intent on fighting for US ratification of the future covenant in order to clear the path of any constitutional barriers to the enactment of national civil rights legislation. Department of State officers, on the other hand, were concerned about the possible harm that might transpire at the international level as a consequence either of non-ratification or of inconsistent subnational legislation and practices. Personal motivations and reasoning probably also diverged. Some were probably either ignorant to or even supportive of existing racial discrimination, or at least unwilling to prioritize ending racial discrimination over other aims. Others probably reasoned in a principled way about what were the proper roles and responsibilities of the different levels of governments. Still others reasoned strategically, trying to avoid politically costly controversies with the Congress and US states. Regardless of motivations, when later developments are taken into account, it seems that the Department of State officers were probably right in their assumptions that the Senate would never support ratification of a human rights covenant, perhaps even if US negotiators had succeeded in securing firm nonself-executing and federal-state clauses, especially if the covenant included social and economic rights.

Thus, the main argument of this article has been that structural mechanisms embodied in the US constitution sharpened domestic political divisions and thereby framed the USA's human rights policy from its inception. The need to include an examination of the role of 
treaties within the US domestic political and legal system in any analysis of US human rights policy becomes clear when a long-term and comparative perspective is adopted. Compared to other UN member states, the US government in the 1940s and early 1950s took very seriously possible immediate domestic effects of treaty ratification during the negotiations of the international bill of rights, scrutinizing the many drafts to identify their possible domestic effects. Given their different political systems and legal cultures, other states were not compelled to focus as systematically on possible gaps between the wording of the treaty and their own domestic laws and practices. They could negotiate and then ratify a treaty, and then at a later stage explore whether changes in domestic laws were necessary in order to comply with the treaty. Few, if any, had a system that resembled that of the United States. Thus, in effect, the USA was barred by its Constitution from making treaty ratification a symbolic act of allegiance to the human rights idea. The practice of adding a series of caveats to international treaties has been invented to lower the threshold for US ratification, and the USA has accordingly ratified several human rights treaties, starting with the Genocide Convention in 1986. The scope of federal legal authority has grown steadily over the last sixty years, and US courts tend to treat treaties as non-self-executing. ${ }^{90}$ Still, with the fundamental role of treaties in the US constitutional system intact, it is seems highly unlikely that we will see swift or unconditional ratification of human rights treaties by the USA in the foreseeable future.

\footnotetext{
${ }^{1}$ For an updated list of the ratification status of principal international human rights treaties, see http://treaties.un.org/Pages/Treaties.aspx?id=4\&subid=A\&lang=en.

${ }^{2}$ The historiography of human rights has expanded quickly since the turn of the century. Pioneering the historical study of human rights, Paul Gordon Lauren's The Evolution of International Human Rights: Visions Seen (3rd edn, Philadelphia: University of Pennsylvania Press, 2011) was first published in 1998 and later revised in 2003 and 2011. The other standard account is A. W. Brian Simpson's Human Rights and the End
} 
of Empire: Britain and the Genesis of the European Convention (Oxford and London: Oxford University Press, 2001), which is far more comprehensive than its title suggests. For a recent work that presents an alternative interpretation of the history of human rights see Samuel Moyn, The Last Utopia: Human Rights in History (Cambridge, MA and London: The Belknap Press of Harvard University Press, 2010). Presenting a collection of very recent historical works is Stefan-Ludwig Hoffmann (ed.), Human Rights in the Twentieth Century (Cambridge: Cambridge University Press, 2011). Possibly the best account of the interwar discussions of human rights is J. H. Burgers, 'The Road to San Francisco' Human Rights Quarterly 14 (1992): 447-77.

${ }^{3}$ John Foster Dulles, 'The Making of Treaties and Executive Agreements', Department of State Bulletin (April 20, 1953): 592.

${ }^{4}$ The main works on US human rights policy in the 1940s and 1950s are Carol Anderson, Eyes off the Prize: The United Nations and the Struggle for Human Rights, 1944-1955 (Cambridge: Cambridge University Press, 2003); Elizabeth Borgwardt, A New Deal for the World: America's Vision for Human Rights (Cambridge and London: Belknap Press, 2005); Mary Ann Glendon, A World Made New: Eleanor Roosevelt and the Universal Declaration of Human Rights (New York: Random House, 2002); Lauren, Visions Seen, and Simpson, End of Empire. See also Carol Anderson 'United States: Race Relations in the 1940s and 1950s and International Human Rights' in David P. Forsythe (ed. in chief), Encyclopedia of Human Rights, Vol 5, 224-33; and Rowland M. Brucken, 'A Most Uncertain Crusade: The United States, Human Rights and the United Nations, 1941-1954' (Ph.D. dissertation, Ohio State University, 1999).

${ }^{5}$ Anderson, Eyes off the Prize. On Eisenhower see also Caroline Pruden, Conditional Partners: Eisenhower, the United Nations and the Search for a Permanent Peace (Baton Rouge: Louisiana State University Press, 1998), esp. pp. 198-204. For accounts of how racism influenced US foreign policy more generally, see Thomas Borstelmann, The Cold War and the Color Line: American Race Relations in the Global Arena (Cambridge and 
London: Harvard University Press, 2001); and Mary L. Dudziak, Cold War Civil Rights: Race and the Image of American Democracy (Princeton: Princeton University Press, 2000).

${ }^{6}$ Roger Normand and Sarah Zaidi, Human Rights at the UN: The Political History of Universal Justice (Bloomington and Indianapolis: Indiana University Press, 2008), 224-30; Brucken, 'A Most Uncertain Crusade', esp. p. 212; Natalie Hevener Kaufman, Human Rights Treaties and the Senate: A History of Opposition (Chapel Hill and London: The University of North Carolina Press, 1990), esp. p. 93; W. Korey, 'The United States and the Genocide Convention: Leading Advocate and Leading Obstacle', Ethics \& International Affairs, 11 (1997), 271-90, esp. p. 281. Only legal historian A. W. Brian Simpson has described in some detail the role of treaties in the United States' constitutional system; see Simpson, End of Empire, $470-5$.

${ }^{7}$ L. Henkin, 'The Constitution, Treaties and International Human Rights', University of Pennsylvania Law Review, 116 (1968), 1012-32; Richard B. Lillich (ed.), U.S. Ratification of the Human Rights Treaties: With or Without Reservations? (Charlottesville: University Press of California, 1981); J. J. Paust, 'Self-Executing Treaties', American Journal of International Law, 82 (1988), 706-83; T. Burgenthal 'The U.S. and International Human Rights', Human Rights Law Journal, 9 (1988), 141-62; J. Goldsmith, 'Should International Human Rights Law Trump US Domestic Law?', Chicago Journal of International Law, 1 (2000), 327-39; M. Shah Alam, 'Enforcement of International Human Rights Law by Domestic Courts in the United States', Annual Survey of International \& Comparative Law, 10 (2004), 27-52; John F. Murphey, The United States and the Rule of Law in International Affairs (Cambridge and New York: Cambridge University Press, 2004). See also Michael Ignatieff (ed), American Exceptionalism and Human Rights, (Princeton and Oxford: Princeton University Press, 2005), esp. pp. 1-27, 147-198, 241-277.

${ }^{8}$ President Truman, Address in San Francisco to the Closing Session of the United Nations Conference, June 26 1945. Available in full text at John T. Woolley and Gerhard Peters, The American Presidency Project [online]. 
Santa Barbara, CA: University of California (hosted), Gerhard Peters (database). Available at http://www.presidency.ucsb.edu/ws/?pid=12188, Accessed 1 Dec. 2010.

${ }^{9}$ Well-kept records from the work of the ISP and its S/HRW are found in RG 353 for the years 1947-9. Later documents reveal that the committee existed after 1949. Its records seem not to have been filed as a group.

${ }^{10}$ Memo, Summary Review of the Conference on the Proposed International Declaration on Human Rights held at the DoS 31 Oct. 1947, RG 59, Lot82D211, box 43.

11 'Proposals on Reservations to Multilateral Conventions' United Nations Bulletin (January 1, 1952), 24-25.

12 Hanne Hagtvedt Vik, 'The United States, the American Legal Community and the Vision of International Human Rights Protection, 1941-1953' (Ph.D. dissertation: University of Oslo, 2009), 76-79, 103-84.

${ }^{13}$ John P. Humphrey, Human Rights and the United Nations: A Great Adventure (Dobbs Ferry: Transnational, 1984), 31-2; U[nited ]N[ations] D[ocument] E/CN.4/AC.1/3/4 June 1947.

${ }^{14}$ UN D, E/600, p. 5.

${ }^{15}$ Memo[randum], OA/McDiarmid ['Working paper on International Bill of Rights prepared by Secretariat'] SD/CS.4/12/Rev., 27 Jan. 1947, RG 59, C[entral] D[ecimal] F[iles[ [19]45-9, box 2187.

${ }^{16}$ Borgwardt, A New Deal for the World, esp. pp. 5-7; Moyn, The Last Utopia, 63-64. See also David MKennedy, Freedom from Fear: The American People in Depression and War, 1929-1945 (New York: Oxford UP, 1999).

${ }^{17}$ US proposals regarding an international bill of rights, E/CN.4/17, 6 Feb. 1947, published in Department of State Bulletin, 16 (16 Feb. 1947), 277.

${ }^{18}$ Simpson, End of Empire, 368ff. 
${ }^{19}$ Memo, Le/Fahy and SPA/Rusk to U/Lovett, 'Drafting Committee - Commission on Human Rights Movement to Draft Convention on Human Rights', 16 June 1947, RG 89, E 1456, [Records of the Bureau of United Nations Affairs, Subject Files, Lot55D323,] box 15; Memo, 'Convention on Human Rights', 18 July 1947, p. 4, RG 59, E 1494-I, Lot62D205, [Office of the] Le[gal Advisor, Division of the] U[nited] N[ations] A[ffairs], box 89 .

${ }^{20}$ Memo, OA/McDiarmid, 27 Jan. 1947, RG 59, CDF 45-49, box 2187.

${ }^{21}$ B. MacChesney, 'Treaty Making Powers and Problems', Illinois Bar Journal, 39 (Sept. 1950), 10-11; C. B. Kelly, 'Treaty Power: Its Scope and Limitations under the Constitution', George Washington Law Review, 19 (1951), 435-38; Frank Ransom Strong, American Constitutional Law (Buffalo: Dennis, 1950), 288, 1439.

22 S/HRW D-125/47, 12 Sept. 1947, RG 353, box 110. See also: S/HRW-D-113/47, 28 July 1947, RG 353, box 110.

${ }^{23}$ S/HRW M-23/47, 28 Sept. 1947, RG 353, box 113.

${ }^{24}$ S/HRW M-23/47, 28 Sept. 1947 and S/HRW M-25/47, 17 Oct. 1947, both RG 353, box 113. A. C. Weinfeld applied a similar generic approach in his 'Are Labor Conditions a Proper Subject for International Conventions?', California Law Review, 24 (1936), 275-87.

${ }^{25}$ Edward S. Corwin, The Constitution and World Organization (Princeton: Princeton University Press, 1944$), 7$.

${ }^{26}$ M. S. McDougal and G. C. K. Leighton, 'The Rights of Man in the World Community: Constitutional Illusions versus Rational Action', Yale Law Journal 59 (Dec. 1949), 95; Strong, Constitutional Law, 1488.

27 S/HRW D-125/47, 12 Sept. 1947, RG 353, B 110. See also: SD/CS.4/12/Rev., pp. 2, 8; 31 Jan. 1947, RG 59, CDF $45-49$, box 2187.

${ }^{28}$ S/HRW M-23/47, 28 Sept. 1947, RG 353, box 113. 
${ }^{29}$ S/HRW R-24/47, 7 Oct. 1947, RG 353, box 113. For a similar conclusion, see D. Riesman, Jr., 'The American Constitution and International Labour Legislation', International Labour Review, 44 (1941), 123-93.

${ }^{30}$ S/HRW D-125/47, 12 Sept. 1947, RG 353, B 110. See also: SD/CS.4/12/Rev., pp. 2, 8; 31 Jan. 1947, RG 59, CDF 45-49, box 2187.

${ }^{31}$ Memo, OA/McDiarmid, pp. 2, 8; 27 Jan. 1947, RG 59, CDF 1945-49, box 2187.

${ }^{32}$ ILO Constitution, Art. 19, Sec. 7. See also: C. Wilfred Jenks, Memorandum for Private Circulation Only, 'Legal Studies bearing upon the Aspects of the Post-War Settlement of Interest to the International Labour Organization', p. 2, C[arnegie] E[ndowment for] I[nternational] P[eace Records, 1910-54, Rare Books and Manuscripts Library, Columbia University, New York], box 59.

${ }^{33}$ S/HRW D-113/47, 'Position Paper on Human Rights Convention', 28 July 1947, RG 353, box 110.

${ }^{34}$ SIP M-13, 15 Aug. 1947, RG 353, box 98.

${ }^{35} \mathrm{Ibid}$. On reactions in the African-American community towards a federal-state clause, see: Anderson, Eyes off the Prize, 137-38.

${ }^{36}$ SIP M-13, 15 Aug 1947, RG 353, box 98.

${ }^{37}$ I have utilized the available finding aids to the records relating to the departments of Labor and Justice in NA but found that these did not easily reveal relevant series. I also made some unsuccessful attempts to locate relevant boxes. Accordingly, the issue is left for future research.

${ }^{38}$ D. R. Maul, 'New Deal Liberalism Going Abroad: David Morse (1907-1990) and the ILO in the Age of American Global Hegemony', unpublished paper delivered to University of Oslo, 26 Aug. 2008. See also Antony Alcock, History of the International Labour Organisation (New York: Octagon Books, 1971), 213. 
${ }^{39}$ William C. Berman, The Politics of Civil Rights in the Truman Administration (Columbus: Ohio State University Press, 1970), 3-9. See also Kevin J. McMahon, Reconsidering Roosevelt on Race: How the Presidency Paved the Road to Brown (Chicago and London: The University of Chicago Press, 2004).

${ }^{40}$ For a critical assessment of the civil rights policy of the Truman administration, see: Anderson, Eyes off the Prize. For more positive assessments, see Berman, Politics of Civil Rights; Michael R. Gardner, Harry Truman and Civil Rights: Moral Courage and Political Risk (Carbondale: Sothern Illinois University Press, 2002). For a contemporary analysis of the plight of the black population, see Gunnar Myrdal, An American Dilemma: The Negro Problem and Modern Democracy (New York: Carnegie Endowment for International Peace, 1944).

${ }^{41}$ S/HRW D-113/47, July 28, 1947, 'Position Paper on Human Rights Convention', RG 353, box 110.

42 S/HRW D-113/47, 28 July, 1947, RG 353, B 110; ISP D-96/47, 12 June 1947, B 110; S/HRW M-16/47, 15 Aug 1947, box 113 .

${ }^{43}$ SPA/Mr. Rusk to LA/Mr. Fahy, 9 July 1947, RG 59 , E 1456, box 15; Notter to Rusk, July 11, 1947, RG 59, CDF 45-49, box 2187; Hendrick to Kotschnig, 18 Aug. 1947; Hendrick to Kotschnig, 17 Sept. 1947, both in RG 59, E 1456, box 15; S/HRW M-23/47, 28 Sept. 1947; S/HRW R-24/47, 7 Oct. 1947; S/HRW M-25/47, 17 Oct. 1947, all in RG 353, box 113.

${ }^{44}$ For discussion of the context as well as these suggestions, see Anderson, Eyes off the Prize, $116 \mathrm{ff}$.

${ }^{45}$ Harry S. Truman, Special Message to the Congress, 2 Febr. 1948: Available at Woolley and Peters, American Presidency Project.

${ }^{46}$ DoS officials disagreed and protested to the D[epartment] o[f] J[ustice]: Memo, OA/Hendrick to Rusk and UNA/Sandifer, 3 Febr. 1948, RG 59, E 1456, box 15.

${ }^{47}$ UN D, E/600, p. 29; also, ISP D-57/48; S/HRW D-29/48 Rev 1, Apr. 23, 1948, RG 353, box 111. 
${ }^{48} \mathrm{C}$. Malik, 'How the Commission on Human Rights Forged Its Draft of a First Covenant', United Nations Bulletin 8 (1 June 1950), 473.

${ }^{49}$ UN D, E/600, p. 37.

${ }^{50}$ UN D, E/600, p. 25.

${ }^{51}$ UN D, E/800, pp. 12-13.

52 Telegr., New York to Secretary of State, 'For Sandifer and Gross', 14 May 1948; RG 59, CDF 45-49, box 2188.

${ }^{53}$ UN D, E/800, p. 12; S/HRW D-87/48, 13 Dec. 1948, RG 353, box 112.

${ }^{54}$ UN D, E/800, p. 5.

${ }^{55}$ S/HRW D-87/48, 13 Dec. 1948, RG 353, box 112.

${ }^{56}$ S/HRW M-33, 13 Dec. 1948, RG 353, box 113.

${ }^{57}$ Manley O. Hudson, 'Suggestions on the Covenant for Mr. Chafee', 20 May 1948; Z. Chafee, Jr. to J. P. Hendrick, 21 May 1948; J. P. Hendrick to Z. Chafee, Jr., 24 May 1948; Z. Chafee, 'Memorandum on Preventing the Covenant on Human Rights from Being Self-Executing', May 1948, all in [Papers of] M[anley] O[ttmer] H[udson, Harvard Law Library, Cambridge, Massachusetts], box 17.

${ }^{58}$ M. O. Hudson to J. P. Hendrick, 26 and 27 May 1948, MOH, box 17.

${ }^{59}$ See, for example, American Bar Association Journal, 34 (Aug. 1948), 698-700; (Sept. 1948), 757-60; (Oct. 1948), 883-84.

${ }^{60}$ See esp. NAACP, An Appeal to the World: A Statement on the Denial of Human Rights to Minorities in the Case of Citizens of Negro Descent in the United States of America and an Appeal to the United Nations for Redress (New York: NAACP, 1947). For details of the petitions from the African-American organizations, 
see: Anderson, Eyes off the Prize, Chapter 2 and pp. 181-209; Brucken, 'Uncertain Crusade', 141-46, 160-62; Brenda Gayle Plummer, Rising Wind: Black Americans and U.S. Foreign Affairs 1935-1960 (Chapel Hill: University of North Carolina Press, 1996), 171-85, 202-4; Paul Gordon Lauren, Power and Prejudice: The Politics and Diplomacy of Racial Discrimination (2nd edn, Boulder and Oxford: Westview, 1996), 184-86.

${ }^{61}$ Humphrey, Great Adventure, 28. See generally: Ton J. M. Zuidwijk, Petitioning the United Nations: A Study in Human Rights (London: St. Martin's Press, 1982), esp. pp. 2-9. See also Lauren, Vision Seen, 217-20; Normand and Zaidi, Human Rights at the UN, 145, 157-66.

62 Memo, NAACP to AAUN, 17 Oct. 1947, C[arnegie ]E[ndowment for] I[nternational ]P[eace ]R[ecords, 191054, Rare Books and Manuscripts Library, Columbia University, New York], box 248.

${ }^{63}$ Minutes, Meeting of the Executive Committee of the AAUN, 4 Dec. 1947, CEIP, B 248. Full reference to the final brief is Shelly v. Kraemer 334 U. S. 1 (1948), Amicus Brief, File Date: 1/5/1948. 37pp. Term Year: 1947. US Supreme Court Records.

64 The report To Secure These Rights is available in full text at: http://www.trumanlibrary.org/civilrights/srights1.htm, see esp. p. 111.

${ }^{65}$ Minutes, Meeting of the Executive Committee of the AAUN, 30 Oct. 1947, CEIP, box 248; Letter, B. V. Cohen to Miss Olsen, 30 Nov 1947, CEIP, box 248.

${ }^{66}$ E. A. Gross (Legal Adviser, DoS), to T. C. Clark (Attorney General, DoJ), 4 Nov. 1947, E 1494-I, LE/UNA, RG 59, box 89. On the government brief, see: Layton, International Politics and Civil Rights, 111-13; Plummer, Rising Wind, 201; Dudziak, Cold War and Civil Rights, 90-2, 275-78.

${ }^{67}$ See, for example: B. V. Cohen, 'Human Rights under the United Nations Charter', Law and Contemporary Problems, 14 (1949), 430-37; Congressional Digest, 'The Influence of Sei Fuji', Congressional Digest 29 (Dec. 1950), 301-2; E. H. Crowell, 'The Declaration of Human Rights, the United Nations Charter and Their Effect 
on the Domestic Law of Human Rights' [Note], Virginia Law Review, 36 (1950), 1059-84; Leon M. Fox, 'United Nations Charter: Its Application as a Treaty to State Law', Boston University Law Review, 30 (Nov. 1950), 555-61; M. O. Hudson, 'Charter Provisions on Human Rights in American Law', American Journal of International Law 44 (July 1950), 543-48; Q. Wright, 'National Courts and Human Rights: The Fuji Case', American Journal of International Law, 45 (Jan. 1951), 62-82; Charles Fairman, 'Finis to Fuji', American Journal of International Law, 46 (1952), 682-90.

${ }^{68}$ On these cases, see: M. P. Bradley, 'The Ambiguities of Sovereignty: The United States and the Global Human Rights Cases of the 1940s and 1950s' in Douglas Howard and Luise White (eds), The State of the Sovereignty: Territories, Laws and Populations (Bloomington and Indianapolis: Indiana University Press, 2009), 124-48; Michael J. Klarman, Unfinished Business: Racial Equality in American History (Oxford and New York: Oxford University Press, 2007), 129-64; J. L. Southard, 'Human Rights Provisions of the U.N. Charter: The History in U.S. Courts', International Law Students Association Journal of International and Comparative Law, 1 (1995), 41-65; B. B. Lockwood, Jr., 'The United Nations Charter and United States Civil Rights Litigation, 1946-1955', lowa Law Review, 69 (1984), 901-56.

${ }^{69}$ For a very short introduction to various systems of incorporation of international law into national law, see David Weissbrodt, National Human Rights Institutions, in Forsythe et al., Encyclopedia of Human Rights, 58-61. Since 1976, US courts have developed extensive human rights jurisprudence based on the Alien Tort Statute (ATS); see Beth Stephens, 'National courts' in Forsythe et al., Encyclopedia of Human Rights, 41-ff. For a study of the Supreme Court rulings on race from 1896 to 1954, see Michael J. Klarman, From Jim Crow to Civil Rights: The Supreme Court and the Struggle for Racial Equality (New York: Oxford University Press, 2004).

70 UN D, E/1371, pp. 8, 60.

71 J. F. Dulles to D. Sandifer, 21 Mar. 1949, RG 59, CDF 45-49, box 2189. 
${ }^{72}$ Cited in Duane Tananbaum, The Bricker Amendment Controversy: A Test of Eisenhower's Political Leadership (Ithaca and London: Cornell University Press), 18n4. For a similar view, see: Memo, Convers. with Edwin Dickinson and Noel Dowling, Draft Covenant on Human Rights, 24 Jan. 1949, RG 59, CDF 45-49, box 2189.

${ }^{73}$ Q. Wright to W. Austin, 17 Jan. 1950; J. F. Green to E. A. Gross, 7 Febr. 1950; Q. Wright to E. A. Gross, 28 Febr. 1950; all in RG 84, $1030 \mathrm{D}$, box 42.

${ }^{74}$ See, for example: Address of A. S. Fisher, Legal Adviser of the DoS, before the California State Bar Association, 2 Sept. 1949, Press Release No. 667, MOH, box 127.

75 'Assembly Approves Plan for Human Rights Covenant', United Nations Bulletin 9 (15 Dec. 1950), 709. A US account of the discussions claimed sixteen countries spoke in favor of the inclusion of a federal-state article, while sixteen countries spoke against: the Dominican Republic and Saudi Arabia were included as speaking in favor: J. Simsarian to H. C. Lodge, Jr., 'Attitude of USSR Toward Federal State Article in Covenant on Human Rights', 31 Oct. 1950, RG 84, 1030 D, box 42.

${ }^{76}$ Max Sørensen and Niels J. Haagerup, Denmark and the United Nations (New York: Manhattan, 1956), 104.

${ }^{77}$ Incom. Telegr., New York to Secretary of State, 15 April 1950, RG 59, CDF 50-54, box 1327. Chile decided to vote negative: Santiago to DoS, 5 May 1950, RG 59, CDF 50-54, box 1327.

${ }^{78}$ Glendon, A World Made New, 196-99.

${ }^{79}$ Res[olution] 421 (V), cited in: Tony Evans, US Hegemony and the Project of Universal Human Rights (Houndmills: Palgrave Macmillan, 1996), 129n32.

${ }^{80}$ Simsarian to Gross, 20 May 1950, RG 84, 1030 D, box 42.

${ }^{81}$ This became later section $D$ in Res. 421(V), ibid. p. 133n45, see also pp. 132-38.

${ }^{82}$ Glendon, World Made New, 199. 
${ }^{83}$ DoS, Public Opinion on the UN; A review of developments April 16-May 15, RG 59, Lot79D273, box 2.

${ }^{84}$ Compare D. Tananbaum, 'The Bricker Amendment Controversy: Its Origins, and Eisenhower's Role', Diplomatic History, 9 (1985), 73-93; Tananbaum, Bricker Amendment Controversy; N. H. Kaufmann and D. Whiteman, 'Opposition to Human Rights Treaties in the United States Senate: The Legacy of the Bricker Amendment', Human Rights Quarterly, 10 (1988), 309-37; and Kaufmann, History of Opposition; with C. J. Nolan, 'The Last Hurrah of Conservative Isolationism: Eisenhower, Congress, and the Bricker Amendment', Presidential Studies Quarterly, 22 (1992), 337-49.

${ }^{85}$ Draft 16 August 1949, attached to J. F. Dulles to J. Simsarian, 16 Aug. 1949; Simsarian to UNA/Sanders, 23 Aug. 1949; both in RG 59, CDF 45-49, box 2190.

${ }^{86} \mathrm{~J}$. F. Dulles, Addr. [to Regional Meeting of the American Association in Louisville, Kentucky, 'Treaty Making and National Unity'], 11 April 1952, RG 59, Lot79D273, box 3. See also Frank E. Holman, The Life and Career of a Western Lawyer, 1886-1961 (Baltimore: Port City, 1963), 527-28.

${ }^{87}$ The standard political biography of John Foster Dulles is Townsend Hoopes, The Devil and John Foster Dulles (Boston: Atlantic-Little, Brown, 1973). See also the more recent Richard H. Immerman, John Foster Dulles: Piety, Pragmatism, and Power in U.S. Foreign Policy (Wilmington, Delaware: SR Books, 1999).

88 J. F. Dulles, Addr., 11 April 1952, RG 59, Lot79D273, box 3.

${ }^{89}$ Evans, US Hegemony, 113.

${ }^{90}$ In the recent Medellín v. Texas, 552 U.S. 491 (2008), the Supreme Court discussed the distinction between self-executing and non-self executing treaties. Medellín had been sentenced to death by a Texan court. In his petition for habeas corpus he argued that an International Court of Justice decition - the Avena decition - was enforceable in US state courts. The Supreme Court found it was not, see M. J. Garcia, 'Can the President 
Compel Domestic Enforcement of an International Tribunal's Judgement? Overview of Supreme Court Decition in Medellín v. Texas', CRS Report for Congress RL34450 (April 10, 2008). 